\title{
GMR
}

\section{Cultivar identification and genetic relationship of pineapple (Ananas comosus) cultivars using SSR markers}

\author{
Y.S. Lin ${ }^{1}$, C.S. Kuan ${ }^{2}$, I.S. Weng ${ }^{1}$ and C.C. Tsai ${ }^{1,3}$ \\ ${ }^{1}$ Crops Improvement Division, \\ Kaohsiung District Agricultural Research and Extension Station, Pingtung, Taiwan \\ ${ }^{2}$ Department of Horticulture, \\ Chiayi Agricultural Experimental Station, Taiwan Agricultural Research Institute, \\ Chiayi, Taiwan \\ ${ }^{3}$ Department of Biotechnology, \\ National Pingtung University of Science and Technology, Pingtung, Taiwan \\ Corresponding author: C.C. Tsai \\ E-mail: tsaicc@mail.kdais.gov.tw \\ Genet. Mol. Res. 14 (4): 15035-15043 (2015) \\ Received April 10, 2015 \\ Accepted July 13, 2015 \\ Published November 24, 2015 \\ DOI http://dx.doi.org/10.4238/2015.November.24.11
}

ABSTRACT. The genetic relationships among 27 pineapple [Ananas comosus (L.) Merr.] cultivars and lines were examined using 16 simple sequence repeat (SSR) markers. The number of alleles per locus of the SSR markers ranged from 2 to 6 (average 3.19), for a total of 51 alleles. Similarity coefficients were calculated on the basis of 51 amplified bands. A dendrogram was created according to the 16 SSR markers by the unweighted pair-group method. The banding patterns obtained from the SSR primers allowed most of the cultivars and lines to be distinguished, with the exception of vegetative clones. According to the dendrogram, the 27 pineapple cultivars and lines were clustered into three main clusters and four individual clusters. As expected, the dendrogram showed that derived cultivars and lines are closely related to their parental cultivars; the genetic relationships between pineapple cultivars agree with the genealogy of 
their breeding history. In addition, the analysis showed that there is no obvious correlation between SSR markers and morphological characters. In conclusion, SSR analysis is an efficient method for pineapple cultivar identification and can offer valuable informative characters to identify pineapple cultivars in Taiwan.

Key words: Ananas comosus; Cultivar identification; Dendrogram; Molecular marker; Pineapple; Simple sequence repeat marker

\section{INTRODUCTION}

Pineapple [Ananas comosus (L.) Merr.], belonging to the family Bromeliaceae, is a perennial herbaceous fruit tree that produces the third most important commercial fruit crop in the world (Botella and Smith, 2008). It is a diploid fruit tree with $2 n=2 x=50$ chromosomes (Smith and Downs, 1979). The plant originated in Brazil, Paraguay, Central and South America. Pineapple cultivars are usually obtained through open pollination and seedling selection (Smith and Downs, 1979) or mutation breeding (Maluszynski et al., 1995).

Modern pineapples originated in pre-Columbian times in South America (Purseglove, 1972). Hume and Miller (1904) divided varieties in Florida into three types, Cayenne, Queen, and Red Spanish, on the basis of the general similarity of morphological characters. Py and Tisseau (1965) and Leal and Soule (1977) further separated Pernambuco and Maipure (Perolera) types from the others, for a total of five horticultural types of pineapple varieties. Although many pineapple cultivars have been bred and described, only a few have been commercialized. As these cultivars have been extensively transferred and have been acclimated in many different countries, they frequently have been renamed. Furthermore, geographical differentiation, clone selection, and cultivar heterogeneity contribute to the confusion. As a result, the classification of pineapple cultivars is very difficult. Many different cultivars are known by the same name and many different names may be given to the same cultivar (Leal, 1990).

Recently, several DNA profiling techniques have been used to identify cultivars and evaluate genetic diversity in pineapple cultivars. Restriction fragment length polymorphism (RFLP) markers have been used to detect chloroplast DNA polymorphism in pineapple (Duval et al., 2001), random amplified polymorphic DNA markers have been used to analyze 18 germplasms of pineapple (Ruas et al., 2001), and amplified fragment length polymorphism (AFLP) markers have been used to clarify the intraspecific DNA polymorphisms of pineapple (Kato et al., 2005). Simple sequence repeats (SSRs) are molecular markers based on tandem repeats of short (2-6 bp) DNA sequences (Litt and Luty, 1989). The copy number of repeats is highly polymorphic, even among closely related genotypes (Brown et al., 1996). The codominant and high polymorphic characteristics of microsatellite loci make them useful in cultivar identification (Chiou et al., 2012; Tsai et al., 2013) and hybrid evaluation (Liao et al., 2012; Chiang et al., 2013). Microsatellite markers (SSRs) of pineapple have been developed and used widely due to their high polymorphism and genome specificity (Kinsuat and Kumar, 2007). SSRs in expressed sequence tags (EST-SSRs) have been developed to analyze cross-amplification in pineapple at the species, genus, subfamily, and family levels (Wöhrmann and Weising, 2011). SSR markers have also been used to discriminate pineapple cultivars in Japan (Shoda et al., 2012).

Pineapple is one of the most important economic fruit crops in Taiwan and its cultivation covers around 9030 ha (Kuan et al., 2012). A breeding program for pineapple has been conducted 
at the Kagi Agricultural Experiment Station in Taiwan since 1926 (Janick and Moore, 1996). During cultivation and propagation, several different types of cultivars and lines have been used as sources of specific characteristics. To establish effective breeding strategies, it is necessary to understand the genetic relationships among pineapple cultivars and to protect new cultivars of pineapple by using molecular markers. In the present study, 16 SSR primers were used to investigate the genetic relationships among 27 pineapple cultivars and lines in Taiwan.

\section{MATERIAL AND METHODS}

\section{Plant materials}

A total of 27 pineapple samples were collected and cultivated at the Department of Life Sciences, National Chung Hsing University, Taiwan (Table 1).

\section{DNA extraction and PCR amplification}

Genomic DNA was extracted from mature leaf powder using the protocol from the Plant Genomic DNA Miniprep System Kit (Viogene, Taipei, Taiwan). A total of 11 (Acom series) and 5 (EST-SSR series) polymorphic SSR markers were derived from Wöhrmann and Weising (2011) and Carlier et al. (2012), respectively, in order to evaluate the genetic relationships of the 27 pineapple cultivars and lines in Taiwan. The designed forward primers for the 16 SSR markers were elongated from the M13 (-21) 18-bp sequence (5'-TGTAAAACGACGGCCAGT-3') by fluorescent labeling (Schuelke, 2000). The designed primer pairs were first tested for PCR amplification and then used to amplify the 27 pineapple cultivars and lines after optimization. PCR conditions were as follows: total volume $25 \mu \mathrm{L}$ with $20 \mathrm{ng}$ of template DNA, 1X PCR buffer, $0.2 \mathrm{mM}$ of each dNTP, $0.2 \mathrm{mM}$ of each SSR specific primer, and $0.25 \cup$ Taq DNA polymerase (Promega, Madison, WI, USA).

Two-step PCR amplification was conducted. The first thermocycling profiles were initial denaturation at $94^{\circ} \mathrm{C}$ for $3 \mathrm{~min}$, followed by 20 cycles of $30 \mathrm{~s}$ denaturation at $94^{\circ} \mathrm{C}, 30 \mathrm{~s}$ annealing at $58^{\circ} \mathrm{C}, 40 \mathrm{~s}$ extension at $72^{\circ} \mathrm{C}$, and a final extension for $7 \mathrm{~min}$ at $72^{\circ} \mathrm{C}$. After that, $0.075 \mathrm{mM} \mathrm{M} 13$ primer 5'-labeled with IRDye was added to the PCR mixture. The second thermo cycling profiles were initial denaturation at $94^{\circ} \mathrm{C}$ for $3 \mathrm{~min}$, followed by 10 cycles of $30 \mathrm{~s}$ denaturation at $94^{\circ} \mathrm{C}, 30$ $\mathrm{s}$ annealing at $58^{\circ} \mathrm{C}, 40 \mathrm{~s}$ extension at $72^{\circ} \mathrm{C}$, and a final extension for $7 \mathrm{~min}$ at $72^{\circ} \mathrm{C}$. Samples were denatured in loading dye $(10 \mathrm{mg} / \mathrm{mL}$ blue dextran in formamide) and separated using $6.5 \%$ polyacrylamide gel (19:1,7 M urea) electrophoresis in a LI-COR 4300 DNA analyzer (LI-COR, Lincoln, NE, USA). Fragment lengths were determined with the aid of an external standard (50-500 bp, GE Healthcare, USA) and with an in-house amplified internal standard using the Allele Locator 1.03 software (Amersham Biosciences, India).

\section{Data analysis}

A total of 51 reproducible bands from 16 SSR primers were scored by length variation as codominant markers for the 27 cultivars and lines studied. The genetic dissimilarities among pineapple individuals were calculated using the methods developed by Bowcock et al. (1994) and Ciampolini et al. (1995), on the basis of pairwise inter-individual comparisons, resulting in a multilocus genetic similarity value complementary to the multilocus genetic distance $(\mathrm{Dm})$ and 


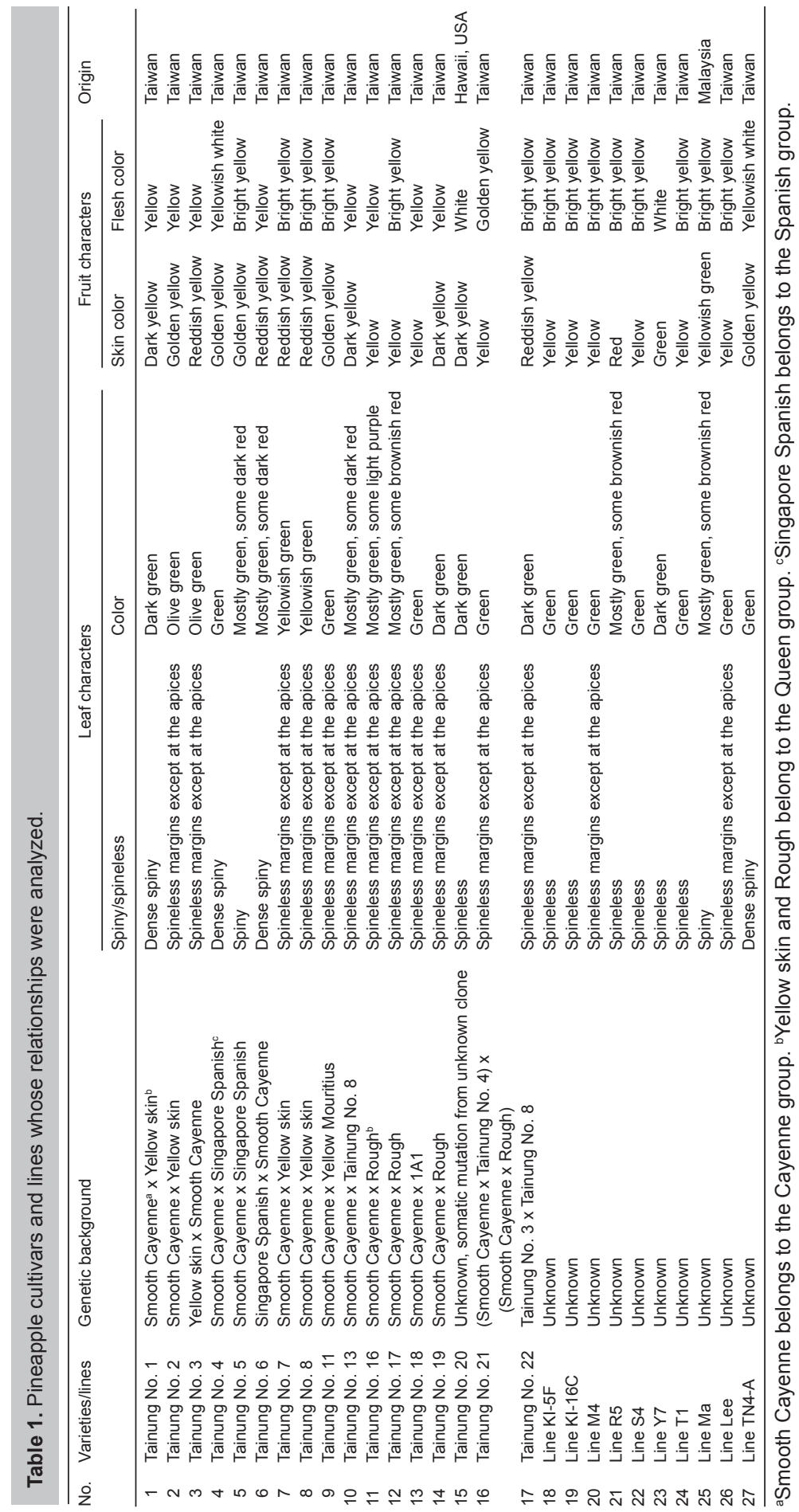


modified to the genetic dissimilarity by $1-\mathrm{Dm}$. Cluster analysis was generated from the pairwise dissimilarity matrix by the unweighted pair-group method (UPGMA) using a molecular evolutionary genetics analysis program (MEGA, version 5.05, Tamura et al., 2011).

\section{RESULTS}

Two electrophoresis graphs are shown in Figures 1 and 2. According to the electrophoretograms, either one or two PCR products were observed for each sample. After data analysis for 16 SSR markers, the number of alleles per locus ranged from 2 to 6 (average 3.19), for a total of 51 alleles. The 27 pineapple cultivars and lines could be successfully distinguished from one another by the 16 SSR markers, with two exceptions: 'Line KI-5F' / 'Line KI-16C' and 'Tainung No. 4' / 'Line TN4-A' (Figure 3).

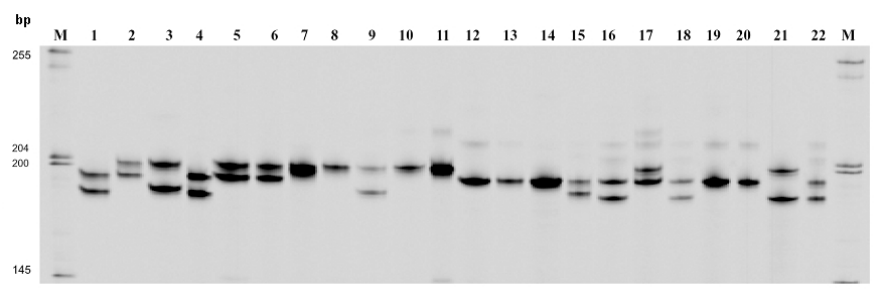

Figure 1. Acom-64.22 simple sequence repeat (SSR) locus analysis of polymorphism in 27 pineapple cultivars and lines. Lane $M=$ DNA marker. Lanes 1-27 = the cultivars and lines listed in Table 1.

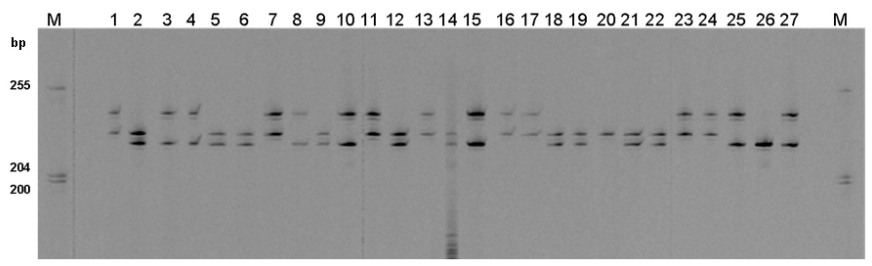

Figure 2. Acom-12.12 simple sequence repeat (SSR) locus analysis of polymorphism in 27 pineapple cultivars and lines. Lane $M=$ DNA marker. Lanes 1-27 = the cultivars and lines listed in Table 1.

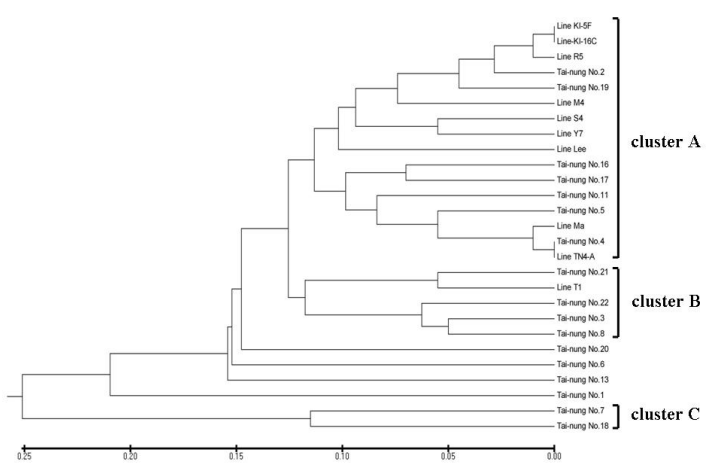

Figure 3. Dendrogram showing the genetic relationships among 27 pineapple cultivars and lines using simple sequence repeat (SSR) markers. The scale bar represents the genetic distance. 
Using the SSR molecular markers of 27 pineapple cultivars and lines, all possible pairwise genetic distances were calculated. They ranged from 0 to 0.78 with an average of 0.26 (Table 2). The dendrogram was obtained by UPGMA analysis. Accessions of 'Tainung No. 7' and 'Tainung No. 21' had the greatest genetic distance, 0.78 , while the two pairs of accessions, 'Tainung No. 4' I 'Line TN4-A' and 'Line KI-5F' / 'Line KI-16C' exhibited the lowest genetic distance, 0.

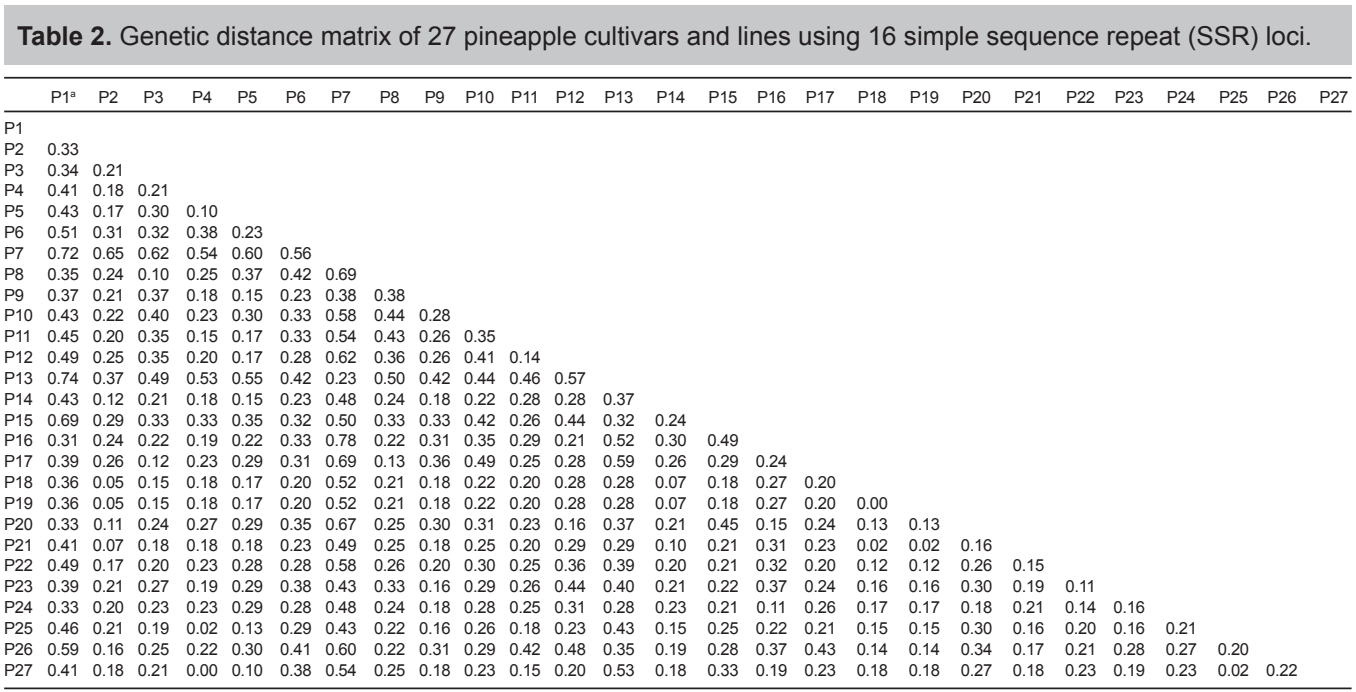

aP1-P27 refer to the pineapple cultivars and lines listed in Table 1.

According to the dendrogram, the 27 pineapple cultivars and lines were clustered into three main clusters and four individual clusters. Cluster A included 'Line KI-5F', 'Line KI-16C', 'Line R5', 'Tainung No. 2', 'Tainung No. 19', 'Line M4', 'Line S4', 'Line Y7', 'Line Lee', 'Tainung No. 16', 'Tainung No. 17', 'Tainung No. 11', 'Tainung No. 5', 'Tainung No. 4', 'Line TN4-A', and 'Line Ma'. Cluster B included 'Tainung No. 21', 'Line T1', 'Tainung No. 22', 'Tainung No. 3', and 'Tainung No. 8'. 'Tainung No. 7' was grouped with 'Tainung No. 18' in cluster C. In addition, 'Tainung No. 20', 'Tainung No. 6', 'Tainung No. 13', and 'Tainung No. 1' belong to individual clusters (Figure 3).

\section{DISCUSSION}

Either one or two PCR products derived from SSR markers were observed for each sample, representing sample homogeneity and heterogeneity, respectively. This result is congruent with the chromosome background of pineapple cultivars which are diploid plants (Smith and Downs, 1979). According to the genetic distance derived from SSR markers of 27 pineapple cultivars in the study, the results show that there is a high degree of genetic variation among pineapple cultivars in Taiwan. This variation has also been revealed in DNA studies of pineapple cultivars by AFLP markers (Kato et al., 2005) and SSR markers (Kinsuat and Kumar, 2007). It may result from the combination of self-incompatibility, high levels of somatic mutation, and intraspecific hybridization in pineapple (Kato et al., 2005).

In cluster A, two local lines, 'Line KI-5F' and 'Line KI-16C', had identical genotypes, indicating that they share the same vegetative clone and are separated from the others. The local 
line 'Line TN4-A' and 'Tainung No. 4' also had the same genotype, indicating that the local line is the vegetative clone of 'Tainung No. 4'. The selected line from Malaya, 'Line Ma' was very closely related to 'Tainung No. 4'. Therefore, we suggest that 'Line Ma' originated from 'Tainung No. 4' and was selected by bud mutation. In addition, 'Tainung No. 5' was closely related to 'Tainung No. 4,' according to the DNA markers. The result agrees with the genealogy of both cultivars, which share the same parents (Yang, 1951; Kang, 1953). 'Tainung No. 16' and 'Tainung No. 17' were also closely related. The result agrees with their breeding history, as they were selected after artificial hybridization using 'Smooth Cayenne' as a female parent and 'Rough' as a male parent (Chang and Kuan, 2001) (Table 1). Other cultivars of the cluster, including 'Tainung No. 2', 'Tainung No. 11,' and 'Tainung No. 19,' were all selected after artificial hybridization using 'Smooth Cayenne' as a female parent and 'Yellow Skin' / 'Yellow Mouritius'/ 'Rough' (Queen type) as a male parent (Yang, 1951; Kang, 1953; Chang and Kuan, 2001). The other local lines of cluster A, including 'Line R5', 'Line M4', 'Line S4', 'Line Y7', and 'Line Lee', can be separated from each of the others. These local lines collected from Taiwan may be further characterized to develop new cultivars. In cluster B, 'Tainung No. 22', 'Tainung No. 3', and 'Tainung No. 8' were very closely related. This result is partially consistent with the breeding history that 'Tainung No. 22' was selected after artificial hybridization using 'Smooth Cayenne' as a female parent and 'Tainung No. 8' as a male parent (Kuan et al., 2012). In cluster C, both 'Tainung No. 7' and 'Tainung No. 18' were selected from hybridization using 'Smooth Cayenne' as a female parent and 'Yellow skin' / '1A1' as a male parent (Yang, 1951; Kang, 1953; Chang and Kuan, 2001).

'Tainung No. 20' was selected from the bud mutation of unknown clones originating from Hawaii (Lin, 2004). This cultivar has a freshly cut surface that is pale in color, differing from the others, all of which have a freshly cut surface that is a bright or dark color (Table 1). This difference explains why 'Tainung No. 20 ' is separated genetically from the others. 'Tainung No. 13' resulted from hybridization using 'Smooth Cayenne' as a female parent and 'Tainung No. 8' as a male parent (Chang and Kuan, 2001). According to its genealogy, this cultivar did not have a unique genetic background or originate from another country outside Taiwan. Therefore, the unique genotype of 'Tainung No. 13' cannot be explained. It might result from the unique direction of selection achieved by the breeder. As for 'Tainung No. 6,' the cultivar resulted from artificial hybridization in a different direction, using 'Smooth Cayenne' as a male parent and 'Singapore Spanish' as a female parent and separated from other cultivars in Taiwan (Yang, 1951; Kang, 1953). This separation produced qualities that place 'Tainung No. 6' in an individual cluster.

According to the dendrogram and morphological characters, there is no obvious correlation between the genotype derived from SSR markers and the phenotype, including the color and texture of the leaf surface, the color of the fruit skin, and the color of the freshly cut surface. Similar results were reported by other studies that used DNA marker analysis to classify pineapple cultivars (Kato et al., 2005; Shoda et al., 2012). Collins (1960) showed that whether the outside edge of the leaf is spiny or lack spines is controlled by a single gene. Fruit skin color is controlled by the accumulation of carotenoids (Brat et al., 2004), chlorophyll degradation (Dull, 1971), and the accumulation of anthocyanins (Brat et al., 2004). The variation in accumulation levels of the different pigments produces a range of skin types, including green, yellow, gold, pink, and red (Sanewski, 2011). The color of the freshly cut fruit is controlled by the accumulation of carotenoids (Dull, 1971; Brat et al., 2004), and white, bright yellow, and dark yellow fruit may be characteristic of different pineapple cultivars (Sanewski, 2011). The accumulation of anthocyanins on the leaf surface is a key factor affecting the phenotype of leaf color. The phenomenon is also very popular in other plants with 
different functional roles (Gould et al., 1995, 2000). The biosynthesis of those plant pigments can be disrupted by one or a few genes (Harvaux and Kloppstech, 2001). Therefore, a difference in one or a few genes can sometimes significantly change plant morphology (Kato et al., 2005), which can explain why there is no correlation between the molecular data derived from SSR markers and the morphological characters observed.

Data from the present study showed that microsatellite markers were useful for evaluation of genetic diversity of pineapple cultivars and lines. Analysis using SSR markers can offer informative characters to identify pineapple cultivars. The genetic relationships among pineapple cultivars in Taiwan essentially agree with the genealogy of their breeding history. However, there is no obvious correlation between the genetics of SSR markers and the morphological characters displayed by the plants.

\section{Conflicts of interest}

The authors declare no conflict of interest.

\section{ACKNOWLEDGMENTS}

We thank Dr. Song-Luan Liaw and Mr. Wen-Kai Wang for collecting and cultivating the plant samples. This research was supported by funding from the National Science Council, Executive Yuan, Taiwan. This study was dedicated to the memory of Dr C.C. Tsai, who passed away on November 5, 2015, in an unexpected stroke. Dr C.C. Tsai was a research scientist studing genetics and breeding at the Crops Improvement Division, Kaohsiung District Agricultural Research and Extension Station, Pingtung, Taiwan.

\section{REFERENCES}

Botella JR and Smith M (2008). Genomics of pineapple, crowning the king of tropical fruit. In: Genomics of Tropical Crop Plants (Moore PH and Ming R, eds.). Springer, New York, 441-451.

Bowcock AM, Ruiz-Linares A, Tomfohrde J, Minch E, et al. (1994). High resolution of human evolutionary trees with polymorphic microsatellites. Nature 368: 455-457.

Brat P, Hoang LNT, Soler A, Reynes M, et al. (2004). Physicochemical characterization of a new pineapple hybrid (FLHORAN41 Cv.). J. Agric. Food Chem. 52: 6170-6177.

Brown SM, Hopkins MS, Mitchell SE, Senior ML, et al. (1996). Multiple methods for the identification of polymorphic simple sequence repeats (SSRs) in sorghum [Sorghum bicolor (L.) Moench]. Theor. Appl. Genet. 93:190-198.

Carlier JD, Sousa NH, Santo TE, d'Eeckenbrugge GC, et al. (2012). A genetic map of pineapple (Ananas comosus (L.) Merr.) including SCAR, CAPS, SSR and EST-SSR markers. Mol. Breed. 29: 245-260.

Chang CC and Kuan CS (2001). Review of pineapple cultivars improvement and future prospects. Symposium of pineapple cultivar improvement and pests and disease management in Taiwan. Chiayi Experiment Branch, Taiwan Agricultural Research Institute, 1-14.

Chiang YC, Huang BH, Chang CW, Wan YT, et al. (2013). Asymmetric introgression in the horticultural living fossil Cycas Sect. Asiorientales using a genome-wide scanning approach. Int. J. Mol. Sci. 14: 8228-8251.

Chiou CY, Chiang YC, Chen CH, Yen CR, et al. (2012). Development and characterization of 38 polymorphic microsatellite markers from an economically important fruit tree, the Indian jujube. Am. J. Bot. 99: e199-e202.

Ciampolini R, Moazami-Goudarzi K, Vaiman D, Dillmann C, et al. (1995). Individual multilocus genotypes using microsatellite polymorphisms to permit the analysis of the genetic variability within and between Italian beef cattle breeds. J. Anim. Sci. 73: 3259-3268.

Collins JL (1960). The pineapple: botany, cultivation and utilization. Interscience Publishers, Inc., New York.

Dull GG (1971). The pineapple: general. In: The biochemistry of fruits and their products. Vol. 2 (Hulme AC, ed.). Academic 
Press, London, 303-331.

Duval MF, Noyer JL, Perrier X, d'Eeckenbrugge GC et al. (2001). Molecular diversity in pineapple assessed by RFLP markers. Theor. Appl. Genet. 102: 83-90.

Gould KS, Kuhn DN, Lee DW and Oberbauer SF (1995). Why leaves are sometimes red. Nature 378: 241-242.

Gould KS, Markham KR, Smith RH and Goris JJ (2000). Functional role of anthocyanins in the leaves of Quintinia serrata A. Cunn. J. Exp. Bot. 51: 1107-1115.

Harvaux M and Kloppstech K (2001). The protective functions of carotenoid and flavonoid pigments against excess visible radiation at chilling temperature investigated in Arabidopsis npq and tt mutants. Planta 213: 953-966.

Hume HH and Miller HK (1904). Pineapple culture II: varieties. Fla. Agr. Exp. Sta. Bull. 70: 33-62.

Janick J and Moore JN (1996). Fruit breeding: volume 1, tree and tropical fruits. Wiley, New York.

Kang YD (1953). Pineapple varieties and strains and their breeding history in Taiwan. Ag. Sci. 1: 15-21.

Kato CY, Nagai C, Moore PH, Zee F, et al. (2005). Intra-specific DNA polymorphism in pineapple (Ananas comosus (L.) Merr.) assessed by AFLP markers. Genet. Resour. Crop Ev. 51: 815-825.

Kinsuat MJ and Kumar SV (2007). Polymorphic microsatellite and cryptic simple repeat sequence markers in pineapples (Ananas comosus var. comosus). Mol. Ecol. Notes 7: 1032-1035.

Kuan CS, Tsai HW and Tan CH (2012). The introduction of Tai-nung No. 22 'Honey Fragrance,' a new pineapple variety. Taiwan Agricultural Research Institute: Technical Service Quarterly Bulletin 92: 6-9.

Leal F (1990). On the validity of Ananas monstruosus. J. Bromeliad Soc. 40: 246-249.

Leal FJ and Soule J (1977). 'Maipure' - a new spineless group of pineapple cultivars. HortScience 12: 301-305.

Liao PC, Tsai CC, Chou CH and Chiang YC (2012). Introgression between cultivars and wild populations of Momordica charantia L. (Cucurbitaceae) in Taiwan. Int. J. Mol. Sci. 13: 6469-6491.

Lin RQ (2004). The introduction of Tai-nung No. 20 'Milk', a new pineapple variety. Taiwan Agricultural Research Institute: Technical Service Quarterly Bulletin 60: 20-22.

Litt M and Luty JA (1989). A hypervariable microsatellite revealed by in vitro amplification of a dinucleotide repeat within the cardiac muscle actin gene. Am. J. Hum. Genet. 44: 397-401.

Maluszynski M, Ahloowalia BS and Sigurbjörnsson B (1995). Application of in vivo and in vitro mutation techniques for crop improvement. Euphytica 85: 303-315.

Purseglove JW (1972). Tropical crops: monocotyledons volumes 1 and 2. Longman, London.

Py C and Tisseau MA (1965). L'ananas - Techniques Agricoles et Productions Tropicales. G.P. Maisonneuve et Larose.

Ruas CF, Ruas PM and Cabral JRS (2001). Assessment of genetic relatedness of the genera Ananas and Pseudananas confirmed by RAPD markers. Euphytica 119: 245-252.

Sanewski GM (2011). Genetic diversity in pineapple. Chronica Horticulturae 51: 9-13.

Schuelke M (2000). An economic method for the fluorescent labeling of PCR fragments. Nature Biotechnol. 18: 233-234.

Shoda M, Urasaki N, Sakiyama S, Terakami S, et al. (2012). DNA profiling of pineapple cultivars in Japan discriminated by SSR markers. Breed. Sci. 62: 352-359.

Smith LB and Downs RJ (1979). Bromelioideae (Bromeliaceae). Flora Neotropica Monograph 14: 1493-2142.

Tamura K, Peterson D, Peterson N, Stecher G, et al. (2011). MEGA5: molecular evolutionary genetics analysis using maximum likelihood, evolutionary distance, and maximum parsimony methods. Mol. Biol. Evol. 28: 2731-2739.

Tsai CC, Chen YK, Chen CH, Weng IS, et al. (2013). Cultivar identification and genetic relationship of mango (Mangifera indica) in Taiwan using 37 SSR markers. Sci. Hort. 164: 196-201.

Wöhrmann T and Weising K (2011). In silico mining for simple sequence repeat loci in a pineapple expressed sequence tag database and cross-species amplification of EST-SSR markers across Bromeliaceae. Theor. Appl. Genet. 123: 635-647.

Yang Z (1951). Manual of fruit trees in Taiwan. Chiayi Experiment Branch, Taiwan Agricultural Research Institute. 